ÉGYPTE

monde arabe

\section{Égypte/Monde arabe}

4 | 2007

Figures de la santé en Égypte

\title{
On Contagion : Sudanese Refugees, HIV/AIDS, and the Social Order in Egypt
}

\section{Minal Giri}

\section{(2) OpenEdition \\ Journals}

Electronic version

URL: https://journals.openedition.org/ema/1769

DOI: $10.4000 /$ ema. 1769

ISSN: 2090-7273

Publisher

CEDEJ - Centre d'études et de documentation économiques juridiques et sociales

\section{Printed version}

Date of publication: 31 December 2007

Number of pages: $179-198$

ISBN: 2-6905838-43-4

ISSN: 1110-5097

Electronic reference

Minal Giri, "On Contagion : Sudanese Refugees, HIV/AIDS, and the Social Order in Egypt", Égypte/ Monde arabe [Online], 4 | 2007, Online since 31 December 2008, connection on 07 July 2022. URL: http://journals.openedition.org/ema/1769 ; DOl: https://doi.org/10.4000/ema.1769 


\section{ON CONTAGION: SUDANESE REFUGEES, HIV/AIDS AND THE SOCIAL ORDER*}

Sometimes disenfranchised masses or hordes of refugees attract the libel, so that they can be put under restraint. Imputing filth to the victims enables them to be rejected without a qualm.

(Douglas, 1991: 725)

In her comparative paper on witchcraft and leprosy, Mary Douglas considers the connection between immorality and disease as a strategy for containing marginalized groups in society (1991). The overlap in accusations of contagion" ("Contagion," 2006) in terms of both "health hazard" and "indecent practices" invokes a familiar archetype tying disease with the imputation of immorality (Douglas, 1991: 725). Often both are ascribed to the "other", a minority population that is perceived as a threat to a larger host community. In

* Many thanks to the editors at Égypte/Monde arabe and Professor Anne Marie Moulin, in particular, for the opportunity to contribute this piece. I would also like to thank Professor David Reisman and Professor Ralph Austen for their encouragement and tireless editing. I am grateful to Professor Barbara Harrell-Bond for sharing her dedication, knowledge and time with me. And to my husband, Asad Q. Ahmed, for granting me his patience, support and his astonishing linguistic expertise.

1. I refer to the "contagion" with consideration of its several interrelated meanings, thus merging the distinction between infectious disease and immoral influence:

1. The communication of disease from body to body by contact, direct or mediated.

2. A contagious disease or sickness; a plague or pestilence.

3. The substance or principle by which a contagious disease is transmitted

4a. A hurtful, defiling, or corrupting contact; infecting influence.

b. A contagious or spreading moral disease; moral corruption.

5. (fig.) The contagious or 'catching' influence or operation of example, sympathy, and the like. 
popular ethical discourse, the exclusion or disenfranchisement of the "other" is frequently based on the possible threat to public health and justified on the grounds of protecting the greatest number (Seidel, 1993: 182). Thus, accusations of contagion may be used to further marginalize the "other" and function as an outward justification for his removal (Gilman \& Nelkin, 1988). Seen or unseen, the imagined or implied threat of contagion can be used as a socioeconomic and political tool to disempower minority populations. ${ }^{2}$

In the following paper, I would like to explore the rhetorical use of contagion as an explanation for the Egyptian government's forced removal of the Sudanese protestors in Cairo on 30 December 2005. Various governmental bodies released several statements of explanation for the forcible evacuation of the Sudanese protestors, describing it as just such a breeding ground of both indecent practices and epidemics (specifically HIV/AIDS). According to Mr. Mufîd Shehâb, Minister of State for the Shûrâ Council, "The situation-in was becoming an increasing security and health hazard that had to be resolved soon" (Transcript of People's Assembly, 2006). This paper explores the use of this kind of language and seeks to understand why these accusations materialized under the rubric of contagion and HIV/AIDS in particular.

I will begin with consideration of the commonly stigmatized link between HIV/AIDS and Africa and its refugees. I will present a brief overview that highlights the main points, as this specific subject has been explored extensively in the spheres of sociology, anthropology and public health literature. When viewed in light of the marginal status of Sudanese refugees in Egypt and the circumstances leading up to the protest, the government rhetoric surrounding the dispersal of the protest offers insight into the treatment of other marginalized or invisible groups in Egyptian society. I will contend that references to the threat of HIV/AIDS, aside from dehumanizing the refugees, reveal Egyptian society's misperceptions regarding HIV/AIDS while exposing its ambivalence toward the silent epidemic brewing within its own borders. I will also attempt to link this rhetoric to a wider discourse on refugees and human rights in Egypt. Thus, the rhetoric serves to reinforce an overt system of social control and ultimately functions to sidestep entirely the question of human rights.

\section{HIV/AIDS AND VULNERABLE GROUPS: HIV/AIDS IN EGYPT}

The phenomenon of HIV/AIDS represents a critical and unsettling example of the politics of disease, particularly since its spread tends to affect the most marginalized groups of society. Across cultures, the spread of HIV/AIDS is

2. "As soon as immorality is associated with infectious disease, the syndrome of social exclusion is buttressed with accusations of causing insidious harm." (Douglas, 1991: 724). 
associated with poverty and inequity. These same structural inequities, in turn, facilitate the further transmission of HIV/AIDS. Just as illness can be used as a political tool, the spread of disease itself often falls along socio-economic lines, where wealth and power determine health care access and quality (Farmer, 1995).

Preliminary reports of HIV/AIDS generated fear and uncertainty in the world community. The first cases were diagnosed among homosexual men in the United States, after which a link to the viral agent of infection was identified in wild chimpanzees living in Southern Cameroon (Gao, et al., 1999). Controversy surrounded early speculation as to the actual spread of infection from monkey to human. Various theories ranging from conspiracy (that the virus was manmade or spread by vaccine inoculation) to promiscuity emerged to explain the transfer of the virus. ${ }^{3}$ From its discovery in the 1980s, HIV/AIDS was imbued with a moral discourse by virtue of its association with so-called degenerate populations that include drug users, homosexuals, and sex workers.

Such widespread conjecture regarding the origins of HIV/AIDS suggests the initial need to assign blame for the disease. In early accounts, HIV/AIDS was often described in terms of cross-border travel, as an imported problem, and thus allowed societies to differentiate themselves from responsibility and avoid taking action against its spread (Sherr \& Farsides, 1996: 71). As previously discussed, immigrants have always shouldered disproportionate blame for social problems such as economic decline, cultural decay and disease, and now popular perceptions of migrants also link them with the spread of HIV/AIDS (Williamson, 2004: 11). Stigmatized groups are commonly defined by any of the following three characteristics: abominations of the body, blemishes of individual character, and the tribal stigma of race, nation or religion (Goffman, 1963: 4). In general, "migrants with HIV/AIDS fulfil all three of these characteristics and are discredited through the process of stigmatization, reduced from a whole person to a tainted and discounted one." (Goffman, 1963: 3) This discourse allows society to control its boundaries, limiting the influx of impoverished foreigners via theories of imported

3. Both national and international travel undoubtedly had a major role in the initial spread of HIV. In the US, international travel by young men making the most of the gay sexual revolution of the late 70s and early 80s would certainly have played a large part in taking the virus worldwide. In Africa, the virus would probably have been spread along truck routes and between towns and cities within the continent itself. However, it is quite conceivable that some of the early outbreaks in African nations were not started by Africans infected with the 'original' virus at all, but by people visiting from overseas where the epidemic had been growing too. The process of transmission in a global pandemic is simply too complex to blame on any one group or individual. (AVERT, 2006). 
disease (Douglas, 1991: 734). Thus, the isolation and stigmatization associated with contagion also serves as a means of defining national, ethnic, or racial boundaries. ${ }^{4}$

Regrettably, the uncontrolled and devastating spread of the infection in sub-Saharan Africa has led to the stereotyping and stigmatization of Africans in general. This prevailing stigma, coupled with the presumed association with migrant populations, has laid a collective groundwork of fear, mistrust and rejection of African migrants. Adding to the current milieu is the widespread political turmoil within several African countries and the subsequent forced migration of masses of refugees into surrounding nations as well as Western countries, an unfortunate set up that bodes poorly for refugees from sub-Saharan Africa. The fact "that the pandemic has flourished in regions such as sub-Saharan Africa only encourages a sense of alienation and detachment from the problem, and a desire to build and reinforce walls against it. This has grave consequences for the international refugee regime as refugees and asylum-seekers from developing countries, like many in sub-Saharan Africa, come to be associated in the public mind with infection and disease. Both issues reinforce the sense of 'us' - healthy, valuable and in need of protection -, against 'them' - infectious and beyond help." (Williamson, 2004: 22)

African refugees are considered a high-risk group because of the increased prevalence of HIV/AIDS in their countries of origin coupled with their vulnerability as victims of human rights abuses and war crimes such as rape. In addition, frequent media associations between Africa and HIV/AIDS have intensified discrimination against Africans, in general, and refugees from Africa, in particular (Williamson, 2004: 5). Thus, the conflation of HIV and refugee in popular press and political discourse contributes to a hostile host environment and further alienation in the host society (Cherfas, 2006: 30). African refugees are subject to repeated marginalization, both in their country of origin and their new host country (decreased access to employment, education, healthcare, etc.) Refugees are thus doubly victimized, having already faced systematic persecution, dispossession and dehumanization in their homelands only to encounter further discrimination in their newly-adopted host countries; "Stigma and discrimination against refugees living with HIV and AIDS continue[s] within refugee communities, as well as the misperception among host communities that refugees [are] 'bringing HIV' "(UNHCR, 2004: 24). The subsequent marginalization actually increases their vulnerability to infection, while simultaneously diminishing the sense of responsibility within the wider community to prevent or respond to the crisis.

4. "For such an analysis, medical diagnosis would have to be brought under the same rubric as 'accusation', and note taken of the destructive effect of some diagnoses on civic status. The result would be a sociological model of the treatment of infectious diseases." (Douglas, 1991: 725) 
An understanding of how HIV/AIDS is perceived in Egyptian society helps to further elucidate the complex association between the protesters and HIV/ AIDS. In the following section I will discuss the phenomenon of HIV/AIDS in Egypt: its prevalence, the prevailing attitudes toward it, and the various measures taken to address the issue. Estimates state that rates of HIV/AIDS in the Middle East are steadily increasing. USAID estimates that there were approximately 5,300 HIV-positive individuals in Egypt in 2005, less than 1\% of the population (USAID, 2005). Compared to its sub-Saharan neighbors, the HIV epidemic in Egypt is classified as low level. In Egypt, as in many Middle Eastern countries, the main mode of transmission is heterosexual, although in Egypt roughly $20 \%$ of infections are contracted by men having sex with men. In general, women tend to acquire HIV/AIDS from their husbands while men acquire it via paid sex, both heterosexual and men having sex with men. The second major mode of HIV/AIDS transmission is via intravenous drug use, an increasingly prevalent problem that cuts across class although the use of illicit drugs is not discussed openly (Kaplan, 2006: 45)

Despite low documented rates of infection, studies show that "sexually active youth, poor health care, three million Egyptians who work outside Egypt without their families, several million tourists, male visitors from other Gulf countries and a large number of refugees and maids who come from high risk countries might change this picture" (El-Gawhary, 1998: 19). Modes of HIV/ AIDS surveillance have not been standardized and implemented to spread awareness and disseminate education on practical prevention measures to the general populations.

The widespread lack of prevention and information on HIV/AIDS in the Middle East springs from cultural and social taboos around the acquisition of the infection, a general discomfort with addressing sexual modes of the transmission of HIV/AIDS. This reluctance coincides with misconceptions regarding populations at risk. In Egypt, where the conservative values prohibit homosexuality and sex before or outside of marriage, it is assumed that HIV/ AIDS infection "happens to other people: namely foreigners, the promiscuous, drug addicts and generally, the morally corrupt." ("Islam Recruited to Help Egyptians Fight HIV," 2006)

This sentiment pervades all segments of society, including the medical sector. "The majority of health workers believe those with HIV should be removed from society, while most university students think 'lewd' people or those 'who have neither values nor principles' are likeliest to get AIDS." ("Islam Recruited to Help Egyptians Fight HIV," 2006) In addition, the assumptions of medical professionals regarding HIV/AIDS contribute to a strongly racialized perception of HIV/AIDS in Egypt. "I have never known any Egyptian HIV patient. I fear that Africans will bring disease like AIDS to Egypt..." (Budiani, 2005: 183). As such, there is no clear evidence to support this claim. "There are dangers involved in the popularization of this notion including overgeneralizations of sub-Saharan Africans being commonly infected with AIDS and Egyptians/Arabs somehow 
immune to it." (Budiani, 2005: 183) "Many Egyptians and health authorities assume that that the HIV/AIDS is contained within these [African] groups." (Budiani, 2005: 184) However, displaced persons are made more vulnerable to HIV/AIDS when they resort to commercial sex work for income generation, as is the case with a number of Sudanese with closed files. The majority of their clients are Egyptian men (Budiani, 2005: 183). As it appears that the protesters were of no immediate danger to the general public, the presumed spread of HIV/AIDS to the community would have most likely occurred via commercial sex. Doctors appearing to have a low degree of suspicion for HIV/AIDS among Egyptians, and therefore not testing for HIV, unwittingly contribute to the under-diagnosis of HIV. ${ }^{5}$ It is not clear whether Egyptians may be dying of diseases that are secondary to HIV such as tuberculosis, cancer, pneumonia, diarrhea without knowledge of the primary source of their illness.

Over the last decade, several efforts have been made in terms of research on the issue and outreach and treatment programs. For example, internationally-sponsored efforts have partnered with local organizations to address the issue. The United Nations Population Fund implemented a prevention program in Egypt along with several other countries. In 2004, Voluntary Testing and Counselling Centres, funded by the United States Agency for International Development (USAID), were established to offer anonymous testing for HIV. These offer anonymous testing along with counselling before and after testing (Budiani, 2005: 179). However, currently many of these centres are encountering financial difficulties due to cuts in funding from the U.S. UNICEF also tracks HIV/AIDS programs with an emphasis on children and young people.

In addition to such efforts, local activists have set up various interventions aimed at addressing the issue of HIV/AIDS. One such project is the National AIDS Hotline program, directed by Dr. Nasr al-Sayyed, head of the National AIDS Program within the Ministry of Health. The hotline was established in 1996 in an effort to answer questions regarding modes of transmission, symptoms and treatment, and the availability of testing centres. The number is advertised in public spaces such as subways and newspapers and receives thousands of calls every month (Budiani, 2005: 179). In 2006, local activists also established a drop-in centre for sex workers. However, proper surveillance and screening have yet to be implemented among high-risk populations such as sex workers, drug users and men who have sex with men. In light of insufficient surveillance of both general and at-risk populations, estimates of the rates of infection may be much lower than the true number of Egyptians living with HIV/AIDS.

5. An example of this kind of failure to diagnose was illustrated by one of my colleagues, an established senior physician. When diagnosing a Sudanese refugee with a penile chancre lesion, he insisted, "It looks like syphilis, but it cannot be - we have no syphilis in Egypt." 


\section{SUDANESE IN EGYPT : CHALLENGES OF RACISM, OBSTACLES TO HEALTH CARE AND LIMITATIONS OF UNHCR}

Having acknowledged the existing stereotypes that link HIV/AIDS to African refugees, this analysis must consider the position of refugees in Egyptian society in particular. Although Egypt presents an uncertain stopping point for thousands of refugees from 36 countries including Ethiopia, Eritrea, Iraq, Palestine, and Somalia, the majority, seventy percent, ${ }^{6}$ of refugees in Egypt come from Sudan. While not all of the Sudanese nationals in Egypt are refugees seeking asylum, ongoing civil war and political unrest in Sudan have driven several distinct waves of Sudanese into Egypt, seeking protection and stability since 1957. Decades of civil war in Sudan have forced over 600,0007 Sudanese to seek refuge in neighbouring countries and approximately 6.1 million have been internally displaced within Sudan (Gottlieb, 2006: 1). Despite the signing of a peace treaty between the North and South, ${ }^{8}$ genocide continues in the Darfur region indicating that the numbers of displaced Sudanese will most likely continue to rise. ${ }^{9}$ Thus, the influx of displaced Sudanese into Egypt has steadily continued over the past two years. In Egypt over the past decade alone, 58,535 Sudanese have registered as asylum seekers with the office of the United Nations High Commissioner for Refugees (UNHCR) Cairo. Of these, 31,990 have been given legal refugee status, 16,000 were rejected and termed "closed files" and some 10,200 of the remaining were given temporary protection as asylum seekers. Of the recognized refugees, 16,675 have been resettled in other countries and 315 are awaiting resettlement (Azzam, 2006: 8-9). Having survived border-crossings and camp conditions, the Sudanese continue their struggles in this new and foreign land. Amidst the daily clamour for food and shelter, they confront the challenges of poverty, racism, violence, disease and insecurity, most often without the protection of the state.

6. Interview with Dr. Barbara Harrell-Bond, American University in Cairo Distinguished Adjunct Professor.

7. As of February 2006, an estimated 201,000 Sudanese refugees are housed in camps in neighboring Chad, 358,000 in Uganda, Ethiopia, Democratic Republic of the Congo (DRC), Kenya, Central African Republic, Egypt, and Eritrea (Gottlieb, 2006: 1).

8. On 9 January 2005, the Government of Sudan and the Sudanese People's Liberation Movement (SPLM) signed a Comprehensive Peace Agreement ending a 21-year civil war between the northern and southern regions of Sudan (Sudan Leaders Sign Historic Deal, 2006).

9. "The ensuing humanitarian emergency in Darfur now affects more than 3.5 million people, including nearly 1.8 million IDPs [Internally Displaced Persons] and approximately 206,000 refugees in eastern Chad. Resolving the crisis in Darfur remains critical to consolidating a national peace and addressing the simmering conflict in eastern Sudan." (Gottlieb, 2006) 
Notwithstanding the obvious structural barriers to the integration of the Sudanese refugee population, the Egyptian government and general public have commonly proclaimed Egypt's long-standing and brotherly relations with Sudan, pointing to a history of porous national boundaries. ${ }^{10}$ However, over the last few centuries, "Egyptian nationalism and culture [has been] shaped by the legacy of race, and by the Sudan as a racial other, long after imperialism and the slave trade had withered away" (Gran, 2006: 108). More recently, unwelcome waves of immigration have contributed to the closing of borders between Egypt and Sudan. Racism against the Sudanese is well-documented and evidenced by the widespread harassment of Sudanese on the streets of Cairo, ranging from racial epithets to housing and employment discrimination (Azzam, 2006: 12-14). According to popular opinion, "Egyptians have lived with Sudanese immigration long enough to have formed comfortable, if stereotypical, views of Sudanese as 'lazy,' 'drunken,' and 'insolent'. Many Egyptians are uncomfortable with the presence of so many Sudanese in their midst." ("Radical Refugees", 2005) Stereotypes combined with "the lack of public knowledge surrounding refugee issues [translate] into hostility, largely based upon the perception that refugees are the source of unemployment and negative behaviours, such as prostitution. Portrayals of refugees in Egyptian media often reinforce such perceptions." (Eidenier, 2006: 28) Discrimination reinforces the overall low socio-economic status among Sudanese refugees as evidenced by the ghettoization of the Sudanese into informal settlements such as Arba'a wa-nuss, one of Cairo's poorest suburbs. ${ }^{11}$ The Egyptian government's policies toward Sudanese refugees (their temporary, non-citizenship status) reinforce societal prejudices against them and together they collude to maintain the alienation of the Sudanese.

Racism combined with socio-economic deprivation lead to indirect and far-ranging health consequences for the Sudanese. For example, the high rate of developmental delay among Sudanese children is very likely linked to nutritional deprivation along with other psychosocial factors. One striking manifestation of malnutrition is the high rate of rickets among Sudanese children, in part secondary to inadequate Vitamin D intake, but also due to a lack of the sunlight essential for converting Vitamin D into calcium inside the body. "This speaks to parents' fears of letting their children play outside during the

10. "Egypt dealt with the crisis with patience and wisdom, taking into consideration that the crisis' parties are the Sudanese brothers." (Transcript of the People's Assembly, 2006)

11. As of 1995, this enclave accommodated approximately 300 Sudanese clustered near a local Sudanese church and school (Le Houérou, 2006). The streets of Arba'a wa-nuss are unpaved, the buildings unfinished and piles of garbage block the main road. Open fires of garbage burn alongside children playing at any given corner. Running water is not guaranteed and often polluted when found. 
day for fear of taunts and mistreatment by Egyptians."12 Malnutrition has been observed even in those children whose families have already been living in Cairo for over two years, implying that resettlement in a new urban setting does not appear to have had a positive impact on their health status.

Discrimination also impacts health outcomes for refugees in terms of their willingness to seek out health care. The UNHCR Cairo contracts with primary and tertiary care facilities via churches, non-governmental organizations (NGOs) and hospitals to care for asylum seekers and refugees. However, the Sudanese generally harbor a deep mistrust of the Egyptian medical system which affects their willingness to access care (Coker, 2004: 411). Sudanese are suspicious of doctors giving them the wrong medicines or overmedicating and medicalizing childbirth (Coker, 2004: 411). Many insist that Sudanese women are subject to higher rates of cesarean sections in order to "steal" their kidneys. ${ }^{13}$ Rumors of rampant organ stealing anecdotes have spread among the refugee communities. While such "urban legends" may reflect an actual market for organs, they also reveal the "fear and resentment of the powerful ruling class" experienced by the refugees (Coker, 2004: 413).

Furthermore, the aforementioned distrust of the medical system spills over into the question of HIV/AIDS in the refugee community. They experience barriers to identification and treatment on several levels. While certain NGOs offer voluntary HIV testing for refugees, options for treatment are limited. Ultimately, treatment for HIV/AIDS infected patients is extremely limited and prohibitively expensive (1,000 U.S. dollars a month). Many of the drugs are not even available in Egypt. In addition to the lack of treatment and the stigma surrounding the infection, the potential legal ramifications of HIV/AIDS imply that the medical establishment works cooperatively with the law enforcement to determine possible resettlement. Australia, for example, largely rejects asylum seekers who are infected with HIV/AIDS or other serious illnesses which may incur large health care costs. The discovery of non-Egyptians who are HIV infected leads to deportation to their country of origin by Egyptian authorities. "Needless to say, this route of return for asylum seekers is much more dangerous than self-initiated returns because Egyptian authorities inform the receiving country's authorities about the specific reason for the deportation." (Budiani, 2005: 185) Asylum seekers frequently avoid the medical establishment when they suspect they are HIV/AIDS infected and this may result in many cases being underreported (Budiani, 2005: 173).

UNHCR Cairo is primarily responsible for the protection of asylum seekers and refugees in Egypt. It conducts refugee status determination interviews, and

12. Interview with physician at Refuge Egypt. Refuge Egypt is a non-profit program that offers a variety of low- cost services including a comprehensive medical program at All-Saints Cathedral in Zamâlek, Cairo.

13. Informal interview with HIV/AIDS health worker at Refuge Egypt. 
provides and coordinates various forms of assistance to refugees. As a signatory to the 1951 Convention and Protocol relating to the Status of Refugees and the 1969 OAU Convention Governing the Specific Aspects of Refugee Problems in Africa, Egypt is obliged to grant recognized refugees several basic rights. ${ }^{14}$

Despite its mandates, however, UNHCR Cairo is limited in its ability to aid refugees and asylum seekers by governmental restrictions on the rights of refugees, as well as by budgetary constraints imposed by chronic funding shortages. For example, "the Office of [UNHCR] plans to assist 19.1 million people in 2006 with a budget of 1.4 billion U.S. dollars. Some of these displaced people, who rely on the refugee agency for assisting with daily survival and for returning to their homes or restarting their lives in a third country, will face hardship and disappointment due to program reductions forced by budget shortfalls. In response to the low initial pledges for its 2006 budget, UNHCR has requested that all offices worldwide operate on $80 \%$ of their projected budgets for 2006." (Mailman, 2006)

In addition, Egypt has made a number of reservations to the articles of the 1951 Convention, notably articles 12 (1) (personal status), 20 (rationing), 22 (1) (access to primary education), 22 (access to public relief and assistance) and 24 (labor legislation and social security)." (Sperl, 2001: 11) "Refugees in Cairo are in a precarious position... because of Egypt's reluctance to make integration a viable option. The large refugee community, mainly composed of Sudanese and Somalis, is stranded in an urban setting without adequate services and support. Furthermore, refugees are prevented from helping themselves due to Egyptian restrictions on refugee employment." (Carnegie Endowment for International

14. The 1951 Convention relating to the Status of Refugees is the key legal document in defining who is a refugee, their rights and the legal obligations of states. "The Convention consolidates previous international instruments relating to refugees and provides the most comprehensive codification of the rights of refugees yet attempted on the international level. It lays down basic minimum standards for the treatment of refugees, without prejudice to the granting by States of more favorable treatment. The Convention is to be applied without discrimination as to race, religion or country of origin, and contains various safeguards against the expulsion of refugees." (United Nations High Commissioner for Refugees )

The 1969 OAU Convention was intended to complement the 1951 Convention. The 1969 OAU Convention expanded the definition of who is a refugee. In comparison to the 1951 Convention, the OAU definition focuses more on the objective circumstances which force displacement. In addition, the definition includes accidental situations not based on deliberate state action. Likewise, the source of danger need not be actions of the state or of its agents. It includes the individual who "owing to external aggression, occupation, foreign domination, or events seriously disturbing public order in either part or in whole of his country of origin [...] is compelled to leave his place of habitual residence." 
Peace, 2006) The Egyptian government has displayed an "unwillingness to permit the legal integration of refugees into Egyptian society. Their presence is still seen as temporary, they are not permitted to work and residence is granted on the understanding that needy cases will be assisted by the UNHCR for the duration of their stay." (Sperl, 2001: 11) Despite the prescribed notion that Egypt should serve as a transit country for the refugees, very small numbers of refugees are actually being resettled in third countries. Thus, some 41,545 Sudanese refugees have been left to fend for themselves amongst the masses of Egypt's poor with limited access to education, healthcare, employment and police protection (Azzam, 2006: 9).

\section{THE PROTEST: THE OFFICIAL GOVERNMENT RHETORIC}

In response to the aforementioned inequities and prolonged insecurity, on September 29, 2005, a group of Sudanese asylum seekers and refugees organized a sit-in near the headquarters of UNHCR Cairo office in the affluent Cairo neighbourhood of Muhandeseen. In particular, the protesters gathered to protest UNHCR policy and the decision to suspend refugee status determination (RSD) interviews. In June 2004, UNHCR Cairo suspended RSD interviews of Southern Sudanese asylum-seekers owing to the signing of the peace agreement by the Government of Sudan and the Sudan People's Liberation Movement/ Army in January 2005 (UNHCR, 2006). Thousands of refugees with temporary yellow cards were left waiting in limbo, unable or unwilling to return to an unstable Southern Sudan and incapable of claiming official recognition in Egypt.

Protesters included people from three groups: recognized refugees holding "blue cards", recent arrivals who held "temporary yellow cards", and those refugees with "closed files" (Azzam, 2006: 8-9). The protesters produced a list of grievances which included the following requests and complaints: refusal of compulsory, involuntary repatriation to southern Sudan; difficulty integrating into Egyptian society due to racism, lack of employment, education and mistrust of the health care system; the reinstatement of refugee status interviews, including the reopening of previously rejected "closed files"; a clearer and transparent process that does not discriminate against Sudanese based on region of origin; protection from the Sudanese government; protection of the vulnerable; protection from arbitrary police detention; investigation of detentions and missing persons and resettlement wherever possible (Azzam, 2006: Appendix A, p. 26). Over the next three months, thousands more gathered to call attention to their difficult living conditions in Egypt, the impossibility of integration into Egyptian society, and the denial of their basic rights as refugees, with the ultimate objective of resettlement in a more hospitable environment.

Ultimately, the protest ended in tragedy, when on the morning of 30 December, 2005 at the behest of UNHCR Cairo, Egyptian security forces surrounded the protesters and forcibly evacuated them from the area. (Le Houérou, 2006). In the ensuing violence, hundreds were injured and at least 
twenty-seven protesters were killed during the forced removal. The Egyptian Ministry of Foreign Affairs initially claimed that the Sudanese who died in the scuffles were "old and sick." However, eleven of those killed were actually children under twelve years of age. ${ }^{15}$ Both local and international media outlets circulated photographs and video footage depicting the brutality of the forced removal. Media reports accused the Egyptian security forces of using excessive force against the protesters. Unfortunately, the Egyptian police force is not well trained in handling the peaceful dispersal of large demonstrations. (Le Houérou, 2006). In the weeks following the incident, the Egyptian Ministry came under intense international scrutiny and criticism for the violent manner in which the situation was handled.

Amidst the chaos regarding the actual numbers of the injured, detained and dead, ${ }^{16}$ both human rights organizations and United Nations officials accused the Egyptian police of using excessive force against the protestors and called for an independent investigation of the matter (Human Rights Watch, 2005). Many expressed their outrage at such violence and loss of life, particularly with regards to the women and children who were killed. The incident was seen as a direct human rights violation and a violation of international mandates to protect refugees. ${ }^{17}$

Various human rights organizations called for an independent investigation of the incident. ${ }^{18}$ According to Joe Stork, Deputy Director of Human Rights Watch's Middle East and North Africa Division, "The high loss of life

15. The Ministry of Foreign Affairs did not release a statement regarding the exact number of persons killed in the Muhandeseen incident until 30 January, 2006, approximately one month after the incident occurred (Ministry of Foreign Affairs Statement, 2006). A 28th person, a boy of 14 years, died in the hospital due to injuries from a beating he received during the forced removal and another man committed suicide while being held in detention (Azzam, 2006: 1, 37, 38).

16. The exact number of persons killed in the Muhandeseen incident (29) was not officially confirmed for several weeks following the protest. In the days following the incident, media reports of the number of people killed varied from anywhere between 10 and 250 .

17. The UNHCR is mandated to lead and co-ordinate international action to protect refugees and resolve refugee problems worldwide. Its primary purpose is to safeguard the rights and well-being of refugees. It strives to ensure that everyone can exercise the right to seek asylum and find safe refuge in another State, with the option to return home voluntarily, integrate locally or to resettle in a third country (UNHCR website, no date). 18. Organizations included the following: International Refugee Rights Initiative, the Refugee Council USA and the Ethiopian Community Development Council ("Refugees Killed in Cairo Protest," 2006), Human Rights Watch ("Egypt: Investigate Police for Sudanese Deaths," 2005), and Amnesty International ("Egypt: Amnesty International calls for inquiry into killings and opposes threatened collective expulsions of Sudanese protesters," 2006). 
suggests the police acted with extreme brutality. A police force acting responsibly would not have allowed such a tragedy to occur... The blood is still on the sidewalks, and already the government is blaming the Sudanese refugees and migrants. Given Egypt's terrible record of police brutality, an independent investigation is absolutely necessary to assess responsibility and punish those responsible." (Human Rights Watch, 2005) United Nations officials publicly expressed sadness and outrage at the event. "Although we still do not have all of the details or a clear picture of what transpired, violence left several people dead and injured. There is no justification for such violence and loss of life," Antonio Guterres, UN High Commissioner for Refugees, said in a written statement ("Annan Slams Cairo Protest Deaths," 2005).

Various branches of the Egyptian government responded with statements explaining the forced removal of the protesters. Of note was the deliberate rhetoric used to characterize the protest as a source of contagion. According to this rhetoric, the protesters posed a threat to public health due to the potential for disease (HIV/AIDS, in particular). These assertions overlapped with claims of the threat to the surrounding community's moral fibre as characterized by allegations of criminal elements, prostitution, public intoxication and filth among the protesters. In the following sections, I will contrast the Egyptian government's rhetoric with the observations of researchers, journalists and non-governmental agency personnel who were in contact with the protesters during the months of the sit-in.

In January 2006, the Egyptian Ministry of Foreign Affairs released a letter to the Parliamentary Group of London concerning the Sudanese Refugees. The letter contained allegations of moral corruption among the protesters in Muhandeseen. "Unfortunately, the population of protesters living in the public garden was rapidly constituting a source of grave concern both to public order and to the residents of the neighbourhood. Hundreds of complaints were filed against their flagrant indecent practices which took place in front of the mosque, an obvious source of discontent for the local inhabitants." (Letter of Egyptian Embassy in London, 2006) Such statements reflect the existing societal stereotypes and bias against the Sudanese.

However, field researchers from the American University in Cairo (who were actually allowed inside the camp to interview protesters) fail to remark or focus on "indecent practices" altogether and instead, describe a highly organized order to this communal society. From the perspective inside the camp and the standpoint of the protesters, "the demonstration became a self-governed community for refugees." (Rowe, 2006: 2) Leaders with an agenda, who were able to become political actors representing both their own interests and those of approximately two thousand others, dominated the protest. They delegated authority, presented grievances, portrayed a specific public image, and negotiated with UNHCR (Rowe, 2006: 2). "The park was transformed into a relatively autonomous community of refugees who created their own sense of security and provided mutual support and solace for each other" (Schafer, 2006: 2). Food was 
shared and the protesters were assigned various roles and tasks within the camp. During the sit-in the demonstrators established many committees, namely: security, media, social and medical (Salih, 2006: 4). The protesters used media, local and international, to disseminate their demands. They even used the media to respond to the UNHCR Cairo's repeated attempts to dismiss them as "economic migrants" and undermine the legitimacy of their demands (Salih, 2006: 5).

In addition, the Egyptian Ministry of Health referred to the material pollution and criminal behaviour associated with the protest. "The sanitary conditions of the 'makeshift camp' were dismal; tree branches in the garden were used to make 'tents'. The prosecution office's report also included many complaints of the neighbourhood inhabitants that the protestors were defecating on the round streets, doing drugs and committing crimes in the park, besides the incident of hitting the Sudanese embassy's driver and other incidents of destruction, fights, and intoxication." (Transcript of People's Assembly, 2006) On the contrary, according to several reports in the popular English-language version of the Cairene newspaper, Al-Ahrâm, ${ }^{19}$ "Most of the protesters are restrained, the impromptu camp orderly despite increasingly harsh conditions, though emotions occasionally flare. As best as possible, a modicum of hygiene is adhered to. Calls of nature are answered care of the Mustafa Mahmoud Mosque, and concerned individuals and organizations regularly hand out food, blankets, and clothing." (Nkrumah, 2005) Arial views of the sit in demonstrate a well-partitioned complex with walls made of banners. The banners carried slogans in both Arabic and English detailing the pleas of the refugees and the reasons for the protest. ${ }^{20}$

The allegations of crimes committed in the park exist alongside reports of constant police presence surrounding the protest. It appears that up until the dispersal of the protest, the protesters were actually on good terms with the police who seemed to play a protective role throughout the three-month period. "Police maintained a constant presence around the park, with some officers in plain clothes and most in uniform. They had a peaceful relationship with the demonstrators." (Azzam, 2006: 21) In fact, it was the protesters themselves who felt in need of protection. According to one protester, "We knew the police were around the park and it was a safe place." (Azzam, 2006: 21)

The People's Assembly also commented on the potential of the protest to cause outbreaks of disease. The Division of Health Affairs in Giza released a report regarding the inspection of the remaining possessions left behind after the dispersal of the protest, stating that "they turned out to be not suitable for human use, dangerous to public health and can be a source of epidemic." (Transcript of People's Assembly, 2006)

19. Although Al-Ahrâm is a government-owned newspaper and generally considered a mouthpiece of the Egyptian government, the English-language version appears to be less "censored" and most likely has little influence within Egyptian society.

20. See Appendix I, "Arial Photograph of Sudanese Protest." 
Several of the protesters had indeed fallen ill with various respiratory ailments during the three-month sit-in. Prolonged exposure to the cold and poor nutrition had weakened their immunity and left many vulnerable to respiratory ailments. Several people had been diagnosed and treated for pneumonia, while some had already been transferred to hospitals long before the forced removal. "At the demonstration, the refugees preferred to provide their own medical treatment. They bought their own medications and IVs and a Sudanese doctor came frequently to check on the group. Only when a person became very ill did they reluctantly go to the hospital." (Schafer, 2006: 9) In addition to the four babies who were born inside the park, "there were seven confirmed deaths prior to the forced eviction, including a toddler, twin infants and an adolescent female." And in the days following the forced removal, hundreds of protesters were triaged in a makeshift clinic located in Sakâkînî Church, the majority of whom had respiratory illness including bronchitis, pneumonia and asthma (which is not infectious). ${ }^{21}$ While this discussion does not account for tuberculosis, which is highly prevalent among the overcrowded, impoverished, and immune-suppressed (both Sudanese and poor Egyptians alike), the individual cases of respiratory illness observed and documented among the protesters did not constitute a threat to the surrounding community.

The People's Assembly debate regarding the removal of the protesters contained warnings of the scourge of HIV/AIDS among protesters. "Furthermore, there have been a lot of warnings against the spread of dangerous epidemic diseases among the protestors that could also spread to the residents of the area where the sit-in took place." (Transcript of People's Assembly, 2006) According to the Ministry of Health, the spread of AIDS between the protesters would lead to "a lot of dangers" (Transcript of People's Assembly, 2006). Successful accusations often consist of crimes that are difficult to prove or disprove and are often directed against groups already hated by the general public (Douglas, 1991: 726). The actual number of Sudanese protesters who had HIV/AIDS was unknown. Furthermore, the protestors had effectively "self-quarantined" themselves off from the community by virtue of their refusal to leave the park. However, the ascription of hidden infection serves to informally entrench the hierarchy of social categories and warn well-placed persons against indiscriminate social intercourse." (Douglas 1991: 726)

21. Approximately 600 or so of the Sudanese protesters were triaged in the week following the forced removal. I personally triaged approximately 60 protesters at Sakâkînî and, of these, roughly 40 individuals presented with pneumonia or asthmarelated complaints. 


\section{CONCLUSION}

The 'grave' threat to public health presented by the Sudanese protest was in actuality a threat to the political status quo. The visibility of this ill-treated minority amidst the backdrop of an upper-class neighbourhood was an open wound upon the fabric of society. ${ }^{22}$ Here was a marginalized group assembled in public, despite laws forbidding public gathering of five or more people. The protesters had the ear of the international community via human rights groups and the media. They commanded international attention alongside the ambivalent protection of the UNHCR Cairo ${ }^{23}$ and posed an even larger threat to the government's authority.

Ultimately, the government's rhetorical use of contagion creates a false dichotomy between Egyptians (healthy, clean) and Sudanese refugees (HIV, dirty). The removal of the protesters provides the illusion of containing a real social blight by isolating it to this particular vulnerable population. "Egypt has the right to maintain social order and it is her right to intervene to end the protest organized by the Sudanese in Mustafâ Mahmûd that continued for three months." (Transcript of the People's Assembly, 2006) While the Egyptian government formally sanctions, which essentially casts the Sudanese refugees as non-entities, it uses certain rhetoric as an informal social control, reinforcing society's pre-existing assumptions regarding Sudanese refugees; it caters to a discourse that has become increasingly racialized against the Sudanese.

In the end, the official rhetoric also encourages the invisibility of Egypt's HIV/AIDS population, so that it continues to live and spread quietly in the shadows. This speaks to Egypt's poor human rights record in general and serves as a warning to other marginalized groups within Egypt, lest they consider mounting a similar protest. Respect for human rights is essential for effective preventative responses to HIV/AIDS and for the elimination of discrimination, as denial of human rights lies at the heart of marginalisation and the creation of vulnerability (Seidel, 1993: 182). By dehumanizing the refugees in an already racialized milieu, they could be discredited, dismissed and disposed of without concern. Thus, the government's rhetoric reinforced certain pervading stereotypes regarding the refugees in Egyptian society, while simultaneously functioning to discredit the refugees' claims for their basic human rights.

22. "Lacking a firm ground on which to establish their identity as legal outsiders, they are liminal persons, open to exploitations... This vulnerability described by unrecognized Sudanese in Cairo is an open wound upon the fabric of society." (Coker, 2004: 402)

23. "Le HCR a dit que le gouvernement égyptien souhaitait briser le mouvement. Et C'est la raison pourquoi je suis tout à fait désolée que l'Égypte soit rendue coupable de tout cela, alors que c'est le HCR qui leur a demandé. La police n'est pas entraînée en Égypte pour disperser les gens de manière pacifique, comme dans d'autres pays d'ailleurs!" (Le Houérou, 2006). 
"Cultural denials are neither wholly private nor officially organized by the state. Whole societies may slip into collective modes of denial not dependent on a fully-fledged Stalinist or Orwellian form of thought control. Without being told what to think about (or what not to think about) and without being punished for 'knowing' the wrong things, societies arrive at unwritten agreements about what can be publicly remembered and acknowledged. People pretend to believe information that they know is false or fake their allegiance to meaningless slogans and kitsch ceremonies. This happens even more in democratic societies. ... Whole societies are based on forms of cruelty, discrimination, repression or exclusion which are 'known' about but never openly acknowledged. These denials may be initiated by the state, but then acquire lives of their own." (Cohen, 2001: 10)

In the current atmosphere, there are no channels open for the discussion or preservation of human rights protections. However this strategy relies on society's tacit agreement, implicating a society that is both complacent and readily compliant in the allocation of inequality. "Dominant groups seem uncannily able to shut out or ignore the injustice and suffering around them. In more democratic societies, people shut out the results not because of coercion but out of cultural habit - turning a blind eye to the visible reminders of homelessness, deprivation, poverty and urban decay." (Cohen, 2001: 5) The example of the forced removal of the Sudanese, although specific to the circumstances of Egypt, represents a snapshot in the ongoing human rights struggle of a growing number of displaced people throughout the world. In an atmosphere of "orange alerts", threats of bioterrorism and debates over torture, it represents one example of the increasingly transparent and desperate attempts to fortify our boundaries against invisible plagues.

\section{CITED WORKS}

Annan Slams Cairo Protest Deaths (December 30, 2005), retrieved April 22, 2006, from http://edition.cnn.com/2005/WORLD/africa/12/30/egypt.sudanese/index.html

AMERA Annual Report 2005, retrieved January 3, 2007, from www.amerauk.org/files/Annual\%20Report\%202005\%20.pdf.

AVERT Web site (October 23, 2006), retrieved January 3, 2007, from http:// www.avert.org/origins.htm.

AzZAM, F. and FMRS Researchers (2006), A Tragedy of Failures and False Expectations: Report on the Events Surrounding the Three-month Sit-in and Forced Removal of Sudanese Refugees in Cairo (September-December, 2005), The American University in Cairo, Cairo, Egypt.

Budiani, D. A. (2005), Quests for Refuge, Quests for Therapy: Displacement, IIIness and the Body in Urban Egypt, Unpublished doctoral dissertation, Michigan State University, Michigan. 
Cherfas, L. (October 2006), Negotiating Access and Culture: Organizational Responses to the Healthcare Needs of Refugees and Asylum Seekers Living with HIV in the UK. RSC Working Paper No. 33, Refugee Studies Centre, University of Oxford, retrieved January 3, 2007, from http://www. rsc.ox.ac.uk/PDFs/WP33\%20Healtchare\%20Provision\%20and\%20HIV \%20LC.pdf.

Comen, S. (2001), States of Denial: Knowing about Atrocities and Suffering, London/New York: Polity Press.

COKER, E. (2004), Dislocated Identity and the Fragmented Body: Discourses of Resistance among Southern Sudanese Refugees in Cairo, Journal of Refugee Studies, 17 (4), 401-419.

Congressional Delegation to Egypt, the Balkans, and the CIS, September 23, 1999, retrieved on January 3, 2007, from http://www.carnegieendowment.org/events/index.cfm?fa=eventDetail\&id=19.

Contagion (2006), OED.com, retrieved January 3, 2007, from http://dictionary. oed.com.

Douglas, M. (1991), Witchcraft and Leprosy: Two Strategies of Exclusion, Man, New Series, 26, (4), 723-736.

Egypt: Amnesty International Calls for Inquiry into Killings and Opposes Threatened Collective Expulsions of Sudanese Protesters, (January 5, 2006), Amnesty International Public Statement, retrieved on January 3, 2007, from http://web.amnesty.org/library/Index/ENGMDE120022006?open\&of $=$ ENG-369.

Egypt: Investigate Police for Sudanese Deaths (December 30, 2005), Human Rights News Press Release, retrieved January 3, 2007, from http://hrw.org/ english/docs/2005/12/30/egypt12353.htm.

Egypt: The Ministry of Foreign Affairs Comments on the Statement Issued by UNHCR(December31,2005), retrieved onJanuary3,2007, from http://www. reliefweb.int/rw/RWB.NSF/db900SID/SODA-6KP4ZK?OpenDocument.

EIDeNIER, E. K. (2006), Providing Health Care Information to Refugees in Cairo: Questions of Access and Integration, American University in Cairo, retrieved January 3, 2007, from http://www.uel.ac.uk/ssmcs/research/fmsc/ papers/Eidenier.pdf.

El-Gawhary, K. (1998), "Breaking the Social Taboo: AIDS Hotline in Cairo", Middle East Report, Power and Sexuality in the Middle East, (206) 1819.

Farmer, P. (1995), "Culture, Poverty, and the Dynamics of HIV Transmission in Rural Haiti", in H. Brummelhuis and G. Herdt (eds.), Culture and Sexual Risk: Anthropological Perspectives on AIDS, Amsterdam, Netherlands: Gordon and Breach Publishers, pp. 3-28.

FARSIDES, C. and L. Sherr (1996), The Person Behind the Virus: Migration, Human Factors and Some Moral and Ethical Questions, in M. Haour-Knipe and R. Rector (eds.), Crossing Borders: Migration, Ethnicity and AIDS, London, England: Taylor \& Francis Publications, pp. 70-85. 
GAO, F., Bailes, E., Robertson, D.L., Chen, Y., Rodenburg, C.M., Michael, S.F., Cummins, L.B., Arthur, L.O., Peeters, M., Shaw, G.M., Sharp, P.M. and B.H. Hahn (1999), "Origin of HIV-1 in the Chimpanzee Pan Troglodytes Troglodytes", Nature, 397 (6718), 436-41.

Gilman, S., and D. Nelkin (1988), Placing blame for devastating disease, Social Research, 55, 361-78.

Goffman, E. (1963), Stigma: Notes on the Management of Spoiled Identity, New York: Simon \& Schuster, Inc.

Gottlieb, G. (March 10, 2006), Sudan - Complex Emergency, USAID Situation Report \#11, retrieved January 3, 2007, from http://www.usaid.gov/our_ work/humanitarian_assistance/disaster_assistance/.

Gran, P. (2006), A Review of a Different Shade of Colonialism: Egypt, Great Britain and the Mastery of the Sudan by Eve M. Troutt Powell. Middle East Studies Association Bulletin 40 (1), 108.

Health Profile Egypt HIV/AIDS, (April 2005), USAID Report, retrieved on January 3, 2007, from http://www.usaid.gov/our_work/global_health/aids/ Countries/ane/egypt_05.pdf.

"Islam Recruited to Help Egyptians Fight HIV" (April 3, 2006), Daily Star, p. 3.

Kaplan, R., (2006) HIV/AIDS in the Middle East and North Africa: A Brief Review of Prevention, Research, and Resources, Middle East Studies Association Bulletin 40 (1), 45-51.

Le Houérou, F., (2006), Forced Migrants and Host Societies in Egypt and Sudan, Cairo Papers in Social Science, 26 (4), 60-61.

Le Houérou, F., (April 28, 2006), Le Drame de la place Mustapha Mahmoud au Caire raconté par Barbara Harrell-Bond interrogée par Fabienne Le Houérou.

TERRA-Editions, Collection "Reflets", retrieved January 20, 2007, from http:// terra.rezo.net/article547.html

Letter of Egyptian Embassy in London to the Parliamentary Group concerning the Sudanese Refugees, (January 30, 2006), Egyptian Ministry of Foreign Affairs, retrieved January 3, 2006, from http://www.mfa.gov.eg/ MFA_Portal/en-GB/MFA_News/Statements/Letter+of+Egyptian+Embassy + in+London+to+the+Parliamentary+Group+concerning+the+Sudanese + Refugees.htm

Mailman, N. (May 30, 2006), Displaced at Risk as UNHCR Faces Donor Shortfalls, retrieved January 3, 2007, from Refugees International.org.

Ministry of Foreign Affairs Statement on the Sudanese Refugees Crisis (January 18, 2006), retrieved January 3, 2007, from http://www.mfa.gov.eg/MFA_ Portal/en-GB/MFA_News/Statements/sud.htm.

Nkrumah, G. (November 17-23, 2005), Radical Refugees, Al-Ahram Weekly On-line, issue 769, retrieved June 25, 2006, from http://weekly.ahram.org. eg/2005/769/feature.htm.

Refugees, HIV and AIDS: Fighting HIV and AIDS together with Refugees, Report on UNHCR's HIV and AIDS Programmes and Activities for 2004, 
Retrieved January 3, 2007, from http://www.unhcr.org/cgi-bin/texis/vtx/ protect/opendoc.pdf?tbl=PROTECTION\&id=430591752.

Refugees International website, http://www.refugeesinternational.org.

Refugees Killed in Cairo Protest, (February 2006), Refugee Rights News [online], Vol. 3, Issue 1, Retrieved on January 3, 2007, from http://www.refugee-rights. org/Newsletters/NorthAfrica/V3N1 RefugeesKilledinCairoProtest.htm.

Rowe, M. (March 2006), Performance and Representation: Masculinity and Leadership at the Cairo Refugee Demonstration, Discussion Panel, Sudanese Refugee Protest in Cairo: Community Dynamics and Broader Implications, The 4th Annual Forced Migration Postgraduate Student Conference, University of East London.

SAlIH, A. K. (March 2006), Sudanese Demonstration in Cairo: Different Stands and Different Opinions, Discussion Panel, Sudanese Refugee Protest in Cairo: Community Dynamics and Broader Implications, The 4th Annual Forced Migration Postgraduate Student Conference, University of East London.

Schafer, S. (March 2006), Solace and Security at the Cairo Refugee Demonstration. Discussion Panel, Sudanese Refugee Protest in Cairo: Community Dynamics and Broader Implications. The 4th Annual Forced Migration Postgraduate Student Conference University of East London.

SeIDEL, G. (1993), "The Competing Discourses of HIVIAIDS in Sub-Saharan Africa: Discourses of Rights and Empowerment vs Discourses of Control and Exclusion", in Social Science and Medicine, 36 (3), 175-194.

SPERL, S. (2001), "Evaluation of UNHCR's Policy on Refugees in Urban Areas: A Case Study Review of Cairo", United Nations High Commissioner for Refugees Evaluation and Policy Analysis Unit, p. 11.

Sudan Leaders Sign Historic Deal (January 9, 2005), retrieved January 4, 2007, from http://news.bbc.co.uk/2/hi/africa/4157707.stm.

The Middle East Regional Overview (2006), UNHCR Global Report 2005, retrieved on January 3, 2007, from http://www.unhcr.org/cgi-bin/texis/vtx/ template?page=publ\&src=static/gr2005/gr2005toc.htm.

Transcript of the People's Assembly debate on the evacuation of Sudanese protesters (January 2, 2006).

UNHCR, Refugee Protection and International Migration (no date), retrieved on January 3, 2007, from http://www.unhcr.org/home/RSDLEGAL/ 44ca0f874.pdf.

Williamson, K. (August 2004), Aids, Gender and Refugee Protection Framework, RSC Working Paper No.19, Refugee Studies Centre, University of Oxford. 